\title{
Comparative digestion of timothy (Phleum pratense) fibre by ruminants, equines and rabbits
}

\author{
BY PETER UDÉN* AND PETER J. VAN SOEST \\ Department of Animal Science, Cornell University, Ithaca, NY 14850, USA
}

(Received 12 June 1981-Accepted 22 September 1981)

\begin{abstract}
1. The abilities of cattle, sheep, goats, equines and rabbits to digest mature timothy (Phleum pratense) hay were compared. Apparent digestibilities were partitioned into true digestibility, metabolic faecal output (MFO) and fibre digestibility. The aim of the study was to determine the relative effects of fermentation site (among groups) and of body-weight (within groups) on the efficiency of digestion.

2. The ruminants were superior to equines, which were in turn superior to rabbits, in digesting fibre components of the hay. A large individual variation in digestibility was noted only for the equines. Increasing body-weight was associated with higher digestibility in ruminants, but no such trends were seen in the non-ruminants.

3. The MFO expressed as a proportion of dry matter intake gave similar values for all groups $(0 \cdot 085-0 \cdot 118)$. As a proportion of available microbial substrate originating from the feed, the values were found to be 0.167 for the ruminant, 0.425 for the equines and 2.13 for the rabbits. The value for the rabbits shows that their lower tract microflora must obtain energy from non-fibre components of the feed. No appreciable digestion of the generated microbes by the host was suggested by the values obtained for the equines.
\end{abstract}

All mammals are dependent on the gut microflora for the digestion of the structural carbohydrates in forage. Since a major portion of the potential digestible energy resides in these components, the organization of the digestive sequence is important in regard to the extraction of energy from this resource.

Animal size may also be a factor favouring different efficiencies of digestion. Small animals require relatively higher digestible energy intakes than do large ones, in accordance with the metabolic size. On the other hand, there is evidence (Parra, 1978) indicating that gastrointestinal and fermentation content increases isometrically with body-weight (interspecies comparison). If comparable foods were eaten, at the same level of intake (as a percentage of metabolic weight), digesta retention time would decrease with decreasing body-weight.

This would predict that smaller animals have a lower digestibility value for fibre than large ones. The metabolic faecal output (MFO) of all herbivores is composed largely of microbial cellular matter (Mason, 1969). Utilization of microbial cells by non-ruminants may be less than that in ruminants because the site of the production lies below that of gastric digestion.

The purpose of this paper is to examine the efficiency of digestion in ruminant and non-ruminant herbivores, as well as the effect of size on digestive capacity.

\section{MATERIALS AND METHODS \\ Management of animals}

Ruminants from $25-610 \mathrm{~kg}$, equines from $95-500 \mathrm{~kg}$ and rabbits from $1 \cdot 3-5 \cdot 4 \mathrm{~kg}$ live weight were selected so as to obtain a wide range of body sizes within each group. Five heifers, four sheep, three goats, two horses, four ponies and four rabbits (two Dutch Belted and two Flemish Giants) were used in the feeding experiments. All animals were mature and fully grown, except two of the heifers that were 12-14 months old.

- Present address: Department of Animal Science, Swedish University of Agricultural Sciences, 75007 Uppsala, Sweden. 
Table 1. Chemical composition $(\mathrm{g} / \mathrm{kg}$ ) of the timothy (Phleum pratense) hay

\begin{tabular}{llr}
\hline & Cell wall & 671 \\
& Cellulose & 291 \\
& Hemicellulose & 292 \\
& Lignin & 84 \\
& Nitrogen & 12 \\
\hline
\end{tabular}

The ruminants were fitted with rumen cannulas, and the equines and rabbits with caecal cannulas. The heifers, two female ponies and the one female horse were fitted with urinary catheters; a urinary collection harness was used on the gelding horse. Sheep, goats and ponies were kept in metabolism crates during faecal collection, heifers and horses were kept in stalls and rabbits were housed in metabolic cages. The rabbits were kept in a metabolism room in which the light cycle was $16 \mathrm{~h}$ light, $8 \mathrm{~h}$ dark. Two digestion trials were made with the rabbits: one trial when coprophagy was allowed and the other when prevention of coprophagy was attempted. In the latter instance, the rabbits were fitted with 220 or $280 \mathrm{~mm}$ wide polyethylene collars.

\section{Feeding}

Animals were fed three times daily except for the rabbits, which were fed once at 16.00 hours. All animals except the rabbits were given a single source of timothy (Phleum pratense) hay as the only feed. The rabbits would not consume enough of the hay to maintain weight, so the hay had to be supplemented and pelleted (hay-supplement $605: 395, \mathrm{w} / \mathrm{w}$ ). The supplements contributed $(\mathrm{g} / \mathrm{kg}$ pelleted diet): cerelose 180 , soya-bean protein 117 , minerals 54, maize oil 30 , vitamins 14 . Hay used for the rabbit pellets was ground to pass a $2 \mathrm{~mm}$ screen. The supplements were chosen so that they would be absorbed before reaching the lower tract. In Table 1 the mean values for the chemical composition of the hay are shown.

The adaptation period to the diet was more than 4 weeks. The timothy was fed in long form to the horses and in chopped form to the other ruminants and ponies.

Feeding levels were regulated at the calculated level for maintenance requirements of digestible energy (National Research Council, 1966, 1971, 1973, 1975) using preliminary digestibility values obtained from each group in a $3 \mathrm{~d}$ collection period.

\section{Faecal collection and analysis}

Faecal collection periods were $7 \mathrm{~d}$ for large heifers, sheep and goats and $5 \mathrm{~d}$ for the other animals. Feed samples were taken daily during the collection period. Faeces were collected and dried in a forced-draught oven at $55^{\circ}$ and analysed for plant fibre constituents according to Van Soest \& Wine (1967), Van Soest (1963) and Van Soest \& Wine (1968). Sulphite was omitted in the preparation of neutral-detergent (ND) fibre due to its effect in solubilizing part of the lignin (Hartley, 1972). Hemicellulose was calculated as the difference between the neutral-detergent residue and the acid-detergent (AD) residue, determined by sequential analysis on the same sample (Bailey \& Ulyatt, 1970). Lignin analysis was made on the ND-AD residue. All residues were calculated on an organic matter basis.

MFO of organic material was calculated as the faecal organic matter soluble in neutral detergent as a proportion of dry matter (DM) intake in the following way:

$$
\mathrm{MFO}=(1-\mathrm{CWC}-\mathrm{NDSash}) \cdot \mathrm{DMI},
$$

where CWC is cell wall content (faeces), DMI is DM indigestibility, NDSash is neutral detergent soluble ash (faeces). 


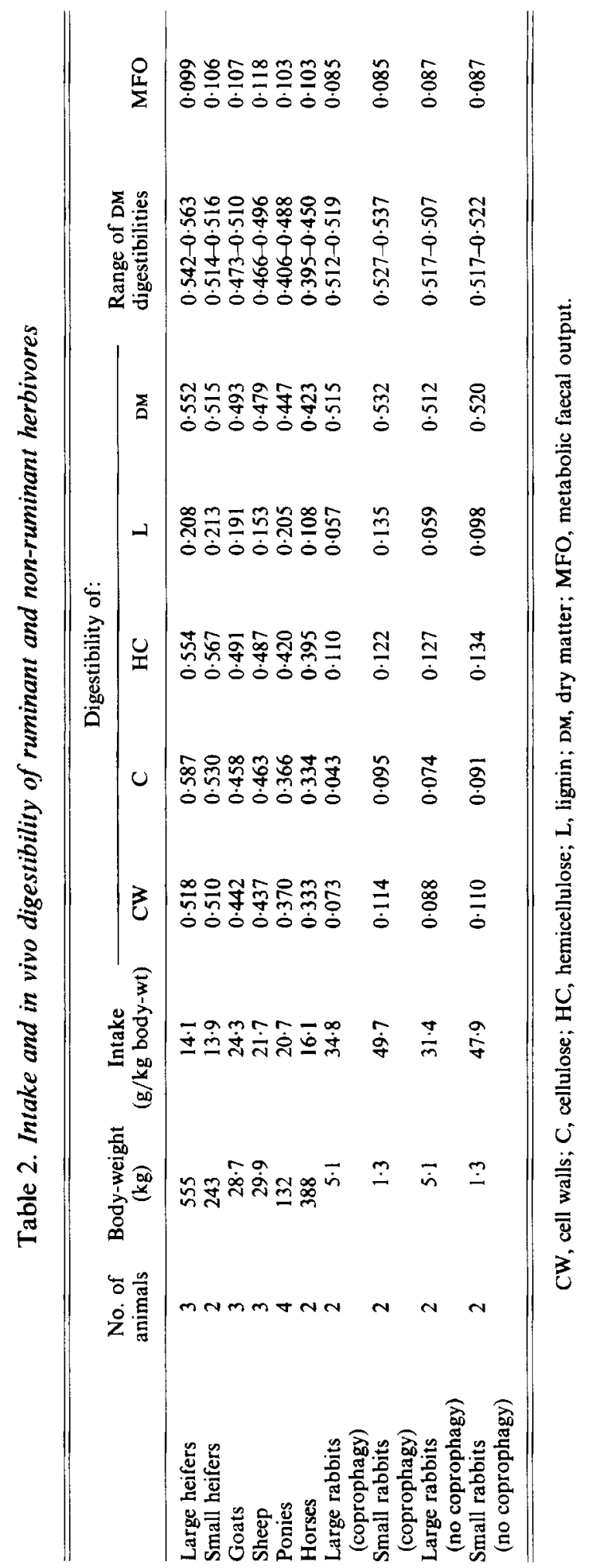


Table 3. Chemical composition $(\mathrm{g} / \mathrm{kg})$ of hard and soft rabbit faeces

\begin{tabular}{|c|c|c|c|c|}
\hline & $\mathrm{CW}$ & $\mathrm{C}$ & $\mathrm{HC}$ & L \\
\hline Hard & 781 & 358 & 311 & 110 \\
\hline Soft & 451 & 203 & 191 & 58 \\
\hline
\end{tabular}

CW, cell wall; C, cellulose; HC, hemicellulose; L, lignin.

Table 4. Cell wall indigestibility (CWID)

\begin{tabular}{|c|c|c|c|c|c|}
\hline \multirow[b]{2}{*}{ Species } & \multirow{2}{*}{$\begin{array}{c}\text { No. of } \\
\text { observations }\end{array}$} & \multicolumn{2}{|c|}{ CWID } & \multirow{2}{*}{$\begin{array}{l}\text { Variance } \\
\left(\mathbf{S}^{2}\right)\end{array}$} & \multirow{2}{*}{$\begin{array}{l}\text { Coefficient } \\
\text { of variation }\end{array}$} \\
\hline & & Mean & SD & & \\
\hline Heifers & 5 & 0.496 & 0.024 & 0.058 & 11.8 \\
\hline Sheep-goats & 6 & 0.561 & 0.021 & 0.043 & 7.6 \\
\hline Equines & 9 & 0.640 & 0.043 & 0.182 & $28 \cdot 3$ \\
\hline Rabbits & 8 & 0.904 & 0.020 & 0.039 & $4 \cdot 3$ \\
\hline
\end{tabular}

\section{RESULTS}

One sheep and one large heifer had to be excluded due to feed refusals of approximately $10 \%$.

The comparison of all species is shown in Table 2 . Fibre digestibility seemed to increase with size in the ruminants. They had the highest fibre digestibility compared to equines and rabbits and also displayed a modest individual variation within each group. Horses and ponies displayed considerable individual variation and were intermediate in fibre digestion between ruminants and rabbits. The largest horse weighing $500 \mathrm{~kg}$ had the lowest value for cell wall digestibility $(0 \cdot 297)$ whilst the smallest pony weighing $90 \mathrm{~kg}$ had the highest $(0 \cdot 437)$.

The rabbits were the poorest fibre fermenters of all and there was little difference in digestibility whether or not they wore neck collars to prevent coprophagy. One rabbit managed to practise coprophagy in spite of the neck collar. It is possible that all rabbits with collars were able to practise some coprophagy even though soft faeces were recovered in the faecal collection. The chemical composition of hard and soft faeces is shown in Table 3. Soft faeces contained much less cell wall, cellulose, hemicellulose and lignin than hard faeces. The small Dutch Belted rabbits seemed to digest the fibre better than the two large Flemish Giants.

Hemicellulose appeared to be more digestible than cellulose in all groups of animals except for the heifers. The relative differences were largest in rabbits and equines. Lignin digestibility was quite variable in most groups. The absolute magnitude can be argued about, as recovery is affected by the total amount of lignin in a sample, as well as the analytical sequence.

The organic MFO varied between $0 \cdot 085-0 \cdot 118$ as a proportion of DM intake, with the rabbits exhibiting the lowest output of all species (Table 2).

Cell wall indigestibilities and associated standard deviations, variances and coefficients of variance are listed in Table 4. From these values it is evident that the equines, as a group, had a considerably larger variation than any other group. 


\section{DISCUSSION}

Lower digestibility in hindgut fermenters as compared to ruminants has been demonstrated by Hintz (1969) and Vander Noot \& Gilbreath (1970). It is quite likely that there is a less potent cellulolytic microflora in non-ruminants (Koller et al. 1978; Van Soest et al. 1978), due to higher rates of passage. Similar results have been obtained in these experiments. Retention time of the cell wall material in the gastrointestinal tract was also significantly shorter for equines and rabbits, as compared with ruminants (Udén, 1978). Digestibility increased with increasing body-weight in the ruminant group, but this was not evident in equines or rabbits.

Hindgut fermenters, e.g. equines and rabbits, appear to have fewer restrictions on the flow of particulate digesta as compared with ruminants where selective retention of fibre is a major feature of reticulo-rumen function. This factor of lesser retention may account for the lower digestibility in equines as compared with ruminants.

Digestibility of cell wall was low in the rabbit in agreement with Snyder (1977) who reported a cell wall digestibility of 0.27 for a high quality brome (Bromus sp.)-timothy hay $(80: 20, \mathrm{w} / \mathrm{w})$ of good quality in Cotton-tail rabbits. For red clover (Trifolium pratense) (mostly leaves) Snyder (1977) reported a cell wall digestibility of 0.59 . This finding suggests that small herbivores are unable to digest a large amount of the slowly-fermenting fibre commonly found in grasses.

The fermentive site in rabbits and other rodents is mainly in the caecum in contrast to equines where the fermentation is largely in the colon. Passage of particulate matter from the caecum of rabbits is faster than liquid (Björnhag, 1972; Uden, 1978). The need for high intake to meet metabolic needs and to overcome limitations of gastrointestinal fill may require this adaptation. The adaptation to a concentrate-selector feeding strategy combined with rapid passage of lignified matter in the hard faeces may allow the rabbit a higher intake and better utilization of the more digestible parts of forage.

Microbial cell mass is one end-product of fermentation besides volatile fatty acids, methane and carbon dioxide. In the ruminants, the whole diet is available to the micro-organisms, whereas in the hindgut fermenters, only the fibre portion of the plant is available. This difference is likely to result in lesser production of microbes in non-ruminants as compared with ruminants.

However, the micro-organisms produced in the foregut will be available to the ruminant when passing through the small intestine and only undigested cell membranes may reach the faeces. In simple-stomached animals faecal matter may be largely composed of living bacteria (Moore et al. 1978). In the hindgut fermenter it is difficult to visualize any digestion and absorbtion of the micro-organisms other than by coprophagy. The MFO per $g$ DM consumed is relatively similar in all groups (Table 2), but if expressed as a proportion of available substrate (assuming complete digestion of non-cell wall material anterior to the lower tract), a different trend is found. Using true digestibility of DM for the ruminants (estimated by the sum of DM digestibility plus MFO) and cell wall digestibility for equines and rabbits, we obtain mean MFO-values of $0 \cdot 167,0.425$ and $2 \cdot 13$ for ruminants, equines and rabbits respectively. These values are obtained assuming MFO is entirely microbial (Mason, 1969). The value for the rabbits exceeds the input of digestible cell wall and indicates either that their microflora must have other sources of a substrate or that rabbit MFO contains substantial non-microbial endogenous matter. Assuming the same efficiency as for the equines $(0.425)$ only approximately $20 \%$ of the rabbits' micro-organisms can come from cell wall alone. In the human and other non-ruminants, endogenously-secreted mucopolysaccharides are a likely important substrate for lower tract fermentation (Vercellotti et al. 1978). 
If the microbes generated in the equine hindgut had been digested as is assumed to be the situation in ruminants, the MFO value would be 0.14 instead of 0.425 , using the mean pepsin digestibility of 0.67 for cellulolytic rumen micro-organisms (Bergen et al. 1967). These values are in reasonable agreement considering the variability of microbial yields, and suggest that lower tract absorption of microbial $\mathrm{N}$ is negligible in equines, in disagreement with the conclusion of Slade (1970).

\section{REFERENCES}

Bailey, R. W. \& Ulyatt, M. (1970). N.Z. Jl agric. Res. 13, 591.

Bergen, W. G., Purser, D. B. \& Cline, J. H. (1967). J. Anim. Sci. 27, 147.

Björnhag, B. (1972). Swedish J. agric. Res. 2, 125.

Hartley, R. D. (1972). J. Sci. Fd agric. 23, 1347.

Hintz, H. F. (1969). The Vet. 6, 45.

Koller, B. L., Hintz, H. F., Robertson, J. B. \& Van Soest, P. J. (1978). J. Anim. Sci. 47, 209.

Mason, V. C. (1969). J. agric. Sci., Camb., 73, 99.

Moore, W. E. C., Cato, E. P. \& Holderman, L. V. (1978). Am. J. clin. Nutr. 31, S33.

National Research Council (1966). Nutrient Requirements of Domestic Animals, no. 9. Washington DC: National Research Council.

National Research Council (1971). Nutrient Requirements of Domestic Animals, no. 3. Washington DC: National Research Council.

National Research Council (1973). Nutrient Requirements of Domestic Animals, no. 6. Washington DC: National Research Council.

National Research Council (1975). Nutrient Requirements of Domestic Animals, no. 5. Washington DC: National Research Council.

Parra, R. (1978). In Ecology of Arboreal Folivores, pp. 205-229 [G. G. Montgomery, editor]. Washington DC: Smithsonian Institution Press.

Slade, L. H. (1970). Nitrogen metabolism in non-ruminant herbivores. PhD Thesis, University of California, Davis, California.

Snyder, W. I. (1977). Feed constituent digestibility by adult and juvenile Cottontail rabbits. PhD Thesis, Cornell University, Ithaca, NY, USA.

Udén, P. (1978). Comparative studies on rate of passage, particle size and rate of digestion in ruminants, equines, rabbits and man. PhD Thesis, Cornell University, Ithaca, NY, USA.

Vander Noot, G. W. \& Gilbreath, E. B. (1970). J. Anim. Sci. 31, 351.

Van Soest, P. J. (1963). J. Ass. Off. agric. Chem. 46, 825.

Van Soest, P. J., Robertson, J. B., Roc, D. A., Rivers, J., Lewis, B. A. \& Hackler, L. R. (1978). Proc. Cornell Nutr. Conf. 1978. p. 5.

Van Soest, P. J. \& Wine, R. H. (1967). J. Ass. Off. agric. Chem. 50, 50.

Van Soest, P. J. \& Wine, R. H. (1968). J. Ass. Off. agric. Chem. 51, 780.

Vercellotti, J. R., Salyers, A. A. \& Wilkins, T. D. (1978). Am. J. clin. Nutr. 31, S86. 